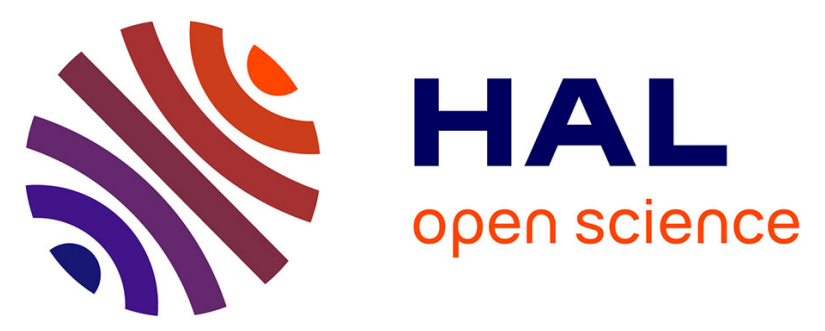

\title{
A biodiversity-friendly rotational grazing system enhancing flower-visiting insect assemblages while maintaining animal and grassland productivity
}

Simone Ravetto Enri, Massimiliano Probo, Anne Farruggia, Laurent Lanore, Andre Blanchetete, Bertrand Dumont

\section{To cite this version:}

Simone Ravetto Enri, Massimiliano Probo, Anne Farruggia, Laurent Lanore, Andre Blanchetete, et al.. A biodiversity-friendly rotational grazing system enhancing flower-visiting insect assemblages while maintaining animal and grassland productivity. Agriculture, Ecosystems and Environment, 2017, 241, pp.1-10. 10.1016/j.agee.2017.02.030 . hal-01607171

\section{HAL Id: hal-01607171 \\ https://hal.science/hal-01607171}

Submitted on 26 May 2020

HAL is a multi-disciplinary open access archive for the deposit and dissemination of scientific research documents, whether they are published or not. The documents may come from teaching and research institutions in France or abroad, or from public or private research centers.
L'archive ouverte pluridisciplinaire HAL, est destinée au dépôt et à la diffusion de documents scientifiques de niveau recherche, publiés ou non, émanant des établissements d'enseignement et de recherche français ou étrangers, des laboratoires publics ou privés.

\section{다(1)(2)}

Distributed under a Creative Commons Attribution - ShareAlikel 4.0 International 


\title{
A biodiversity-friendly rotational grazing system enhancing flower-visiting insect assemblages while maintaining animal and grassland productivity
}

\author{
Simone Ravetto Enri ${ }^{\mathrm{a}}$, Massimiliano Probo ${ }^{\mathrm{a}}$, Anne Farruggia ${ }^{\mathrm{b}, *}$, Laurent Lanore ${ }^{\mathrm{b}}$, \\ André Blanchetete ${ }^{\mathrm{c}}$, Bertrand Dumont ${ }^{\mathrm{b}}$ \\ a Department of Agriculture, Forest and Food Sciences, University of Torino, Largo Paolo Braccini 2, 10095 Grugliasco, TO, Italy \\ b INRA, UMR1213 Herbivores, Vetagro Sup, F-63122 Saint-Genès-Champanelle, France \\ ' INRA, UE1414 Herbipôle, F-63122 Saint-Genès-Champanelle, France
}

\section{A R T I C L E I N F O}

\section{Article history:}

Received 21 September 2016

Received in revised form 20 February 2017

Accepted 21 February 2017

Available online $\mathrm{xxx}$

\section{Keywords:}

Butterflies

Cattle

Flower cover

Grazing management

Ground beetles

Sheep

\begin{abstract}
A B S T R A C T
Grazing management is an important tool to preserve insect biodiversity. Although literature has discussed the importance of grazing pressure adjustment to support grassland insect communities for the ecosystem services they provide, little has been published on the economic sustainability of such management adjustments to date. This study compared continuous grazing (CG) to an innovative rotational grazing system (the biodiversity-friendly rotation - BR), where a subplot was excluded from grazing for two months during the main flowering period. The effects of grazing two different species (cattle and sheep) within both systems were also evaluated. The aims were to assess the effects on butterfly, bumblebee, and ground beetle assemblages, along with the impact on herbage mass and animal performance. The BR enhanced both the abundance and species richness of flower-visiting insect assemblages and it was observed that cattle provided better results than sheep grazing. A multivariate redundancy analysis highlighted that most of the flower-visiting species (including almost all the endangered and locally rare species) were favoured by BR-cattle treatment, mainly due to the high percentage of flower cover and sward heterogeneity involved in this treatment. However, grazing system and grazer species did not affect ground beetle species richness or abundance. Moreover, herbage mass and animal performance (live weight and body condition score) were comparable between CG and BR throughout the grazing season. The BR could be a useful management system to enhance grassland flower-visiting insect assemblages whilst meeting farm production objectives, especially in protected environments where insect conservation is a major target.
\end{abstract}

(C) 2017 Elsevier B.V. All rights reserved.

\section{Introduction}

The sustainability of animal production systems has become a major issue over the last few years (Altieri, 2002; Brym and Reeve, 2016; Craheix et al., 2016; Tilman et al., 2002), emphasizing the need to optimize land-use, mitigate and adapt to climate change and to reduce biodiversity loss (Phalan et al., 2011; Seppelt and Voinov, 2002). Agro-pastoral systems play a pivotal role in this context (Soussana et al., 2014) as they must maximize the benefits provided to human society and the biosphere, such as food production and ecosystem functioning (Rey et al., 2015).

\footnotetext{
* Corresponding author.

E-mail address: anne.farruggia@clermont.inra.fr (A. Farruggia).
}

After several millennia of land management, agro-pastoral systems have contributed to create a wide variety of semi-natural habitats, often characterised by high biodiversity levels (Orlandi et al., 2016). Mountain grasslands, which have been mainly created and maintained by extensive cattle and sheep grazing and/or mowing, are among the most biodiverse habitats in Europe (Dengler et al., 2014) and the sustainability of the traditional management of these ecosystems is currently under constant threat due to socio-economic and market changes (Bernués et al., 2011; Dong et al., 2011). Indeed, the increase in production costs and reduction in product sale incomes have often led to an intensification of grassland management within the most productive sites, along with grassland abandonment when management has become unprofitable (Agnoletti, 2014; Caballero, 2015). In both cases, changes in management led to changes in grassland 
productivity and in an overall decrease in plant and animal diversity (Báldi et al., 2013; Orlandi et al., 2016; Sjödin et al., 2008; Söderström et al., 2001). Moreover, the highest biodiversity in these semi-natural ecosystems is generally associated to intermediate levels of management intensity, in agreement with the intermediate disturbance hypothesis (Cingolani et al., 2005; Grime, 1973; Yan et al., 2015). Within permanent mountain pastures, optimal livestock pressure for biodiversity conservation can be achieved by using specific pastoral practices (Pittarello et al., 2016a, 2016b) and/or by adjusting the number of grazing animals, the area available for grazing, the grazing schedule and system (e.g. rotational or continuous grazing; Farruggia et al., 2014; Probo et al., 2014). Nowadays, a major challenge is that of applying innovative management systems able not only to preserve plant and animal diversity but also to maintain levels of animal and grassland productivity.

Several studies focused on grassland insect communities so as to monitor the effects of different grazing regimes produced on grassland biodiversity as they can be considered key groups due to the fact that their assemblages are immediately and severely affected by habitat changes (Tocco et al., 2013). Moreover, grassland insect communities include a wide variety of species threatened by habitat loss and modification (Ewers and Didham, 2006), including several protected by local, national or EU legislation, such as the Habitat Directive (92/43/EEC). Livestock pressures on grassland habitats may have varying effects on insect communities in different ways, as reported by van Klink et al. (2015), including: i) modification of the abiotic conditions (modification of vegetation patches, a decrease in vegetation height, an alteration in structural complexity, and changes in soil conditions), ii) varying the feeding resource availability (flower and herbage mass reduction, the rate of dung depositions, and live tissue accessibility), and iii) ingestion or trampling by the grazing animals. Each of these actions depends on livestock species and management, due to grazer/browser feeding preferences, live weight and social behaviour (Iussig et al., 2015; van Klink et al., 2015). Amongst the most common grazer species, the higher selectivity of sheep for legumes and forbs and flowering plant parts can lead to grass-dominated plant communities with a lower diversity of nectar-dependent insect taxa than cattle-grazed grasslands (Dumont et al., 2011; Öckinger et al., 2006).

Furthermore, Sjödin et al. (2008) highlighted that it is essential to consider different insect taxa simultaneously in a systemic research as the effects of livestock pressure on insect diversity and abundance may differ when more than a single insect group is taken into consideration. Nevertheless, while multi-taxon approaches have been largely applied to compare variations in diversity and abundance for various insect groups at variable grazing pressures (Scohier and Dumont, 2012; Sjödin et al., 2008; Wallis De Vries et al., 2007), the simultaneous effects of different grazing systems and grazer species on a given plant community have, to date, been only scantily evaluated. Scohier et al. (2012) focused only on sheep grazing and observed that a particular rotational grazing system, with sheep exclusion from pasture during the main flowering period as proposed by Farruggia et al. (2012), was more beneficial for bumblebees than it was for butterflies. Zhu et al. (2015) focused on rationed grazing system with cattle, sheep and goats and recorded different responses of six insect groups (grasshoppers, homopterans, beetles, dipterans, hemipterans and butterflies) according to the grazer species, without considering grassland or animal performance during the grazing season. Contrasting results were reported in other studies that focused only on grassland and animal performance under continuous and rotational grazing systems, without considering their effect on insect diversity (e.g., Savian et al., 2014).
The present study aimed at assessing the effects produced by two grazer species (cattle and sheep) managed at the same stocking density under two grazing systems, i.e. continuous grazing (CG) and an innovative rotational grazing system to enhance biodiversity (the biodiversity-friendly rotational grazing system - BR), on three insect taxa (butterflies, bumblebees and ground beetles), as well as on herbage mass and animal performance. Butterflies and bumblebees were chosen for their role in pollination as flower-visiting insect taxa, whilst ground beetles were chosen as they represent a large insect taxon related to grassland structure, with different feeding behaviours (often carnivorous; van Klink et al., 2015) and as indicators of invertebrate abundance and Coleoptera richness (Cameron and Leather, 2012). The following hypotheses were tested: i) insect abundance and diversity would be enhanced by the BR, ii) sheep grazing would be detrimental for flower cover and, consequently, for insect assemblages, iii) benefits would differ among insect taxa, and iv) BR would not differ from CG in terms of herbage mass or animal performance.

\section{Materials and methods}

\subsection{Study area}

The grazing experiment was established in semi-natural mountain pastures managed by INRA (Institut National de Recherche Agronomique) in the upland area of central France, within the Volcans d'Auvergne Natural Park (Massif Central, $\left.45^{\circ} 15^{\prime} \mathrm{N}, 2^{\circ} 51^{\prime} \mathrm{E}\right)$. The study area was located at $1100 \mathrm{~m}$ a.s.l. and it was characterised by volcanic soils and sub-Atlantic climate (Köppen's classification: Cfb, Climate-Data.org, 2016) with average annual temperature of $7.0^{\circ} \mathrm{C}$ and precipitation of $1169 \mathrm{~mm}$ (average values for the period 1965-2010 according to the Marcenat weather station). Pastures without mineral fertilization had been extensively grazed by cattle since 1992 (Dumont et al., 2009). The dominant plant community belonged to the Cynosurion cristati alliance, sensu Braun-Blanquet et al. (1932).

\subsection{Experimental design}

In the years 2011, 2012 and 2013, continuous grazing (CG) was compared to an innovative rotational grazing system (hereafter referred to as 'biodiversity-friendly rotation', BR), i.e. a system in which enclosures (plots) were divided into four subplots (A-D), each one grazed for 35 days per year, with subplot $D$ excluded from grazing for 63 days during the main flowering period, i.e. from early-June to early-August (see Annex A in Supplementary material). Two grazer species in the experimental design were compared (cattle and sheep) and each grazing system $\times$ grazer species treatment was replicated three times in a complete randomized design, so that 12 plots were set up (see Annex B in Supplementary material). A total of six 3.6 ha plots were grazed by seven Charolais heifers (corresponding to 6.30 livestock units) each and six 0.6 ha plots were grazed by seven Limousine ewes (corresponding to 1.05 livestock units) each, providing a comparable stocking density (1.75 livestock units ha ${ }^{-1}$ ), which is in line with the local stocking density commonly applied in the region.

The plots were chosen with similar elevation, exposure, roughness and slope and each one had a randomly positioned water source to meet animal requirements. Moreover, grassland botanical composition was evaluated before setting the experiment up according to the characterisation made by a botanist (see Acknowledgements), to ensure that both plots and subplots were set-up on a similar plant community. 


\subsection{Data collection}

\subsubsection{Flower cover and sward structure}

The detailed botanical composition of the plots and subplots was recorded only once in July 2011, as no significant changes in plant community composition due to the grazing treatments were expected in the time span under investigation (2011-2013), since the vegetation dynamics in these permanent mountain grasslands are slow (Dumont et al., 2011). The botanist carried out botanical surveys during the main flowering period, i.e. at the maximum trophic availability for flower-visiting insects. In each plot, ten 1$\mathrm{m}^{2}$ quadrats were set and the relative abundance (\%) of each plant species was assessed along eight quadrat points within each quadrat, so that a total of 80 quadrat points per plot were performed. A minimum value of $0.3 \%$ was assigned to occasional species (Tasser and Tappeiner, 2005), i.e. to the species not recorded along the quadrat points but occurring within a range of $5 \mathrm{~m}$ from the quadrat itself. Grassland plant diversity was assessed according to the Shannon diversity index (Magurran, 1988) for each plot and subplot and the relative abundance (\%) of species pollinated by butterflies and bumblebees (Landolt et al., 2010; Ferrazzi and Vercelli, 2016) was calculated.

During the flowering peak (July), the flower cover percentage was visually estimated by the same observer in eight $30 \times 30 \mathrm{~m}$ squares within each plot (two per BR subplot), twice yearly (Farruggia et al., 2012) (see Annex A in Supplementary material). The percentage covers of yellow, white and purple-pink flowers in each square were noted during each observation and then used to calculate an overall flower cover.

Sward surface heights were measured monthly during the exclusion period (see Annex A in Supplementary material) with a graduated stick (Barthram, 1984) along regular transects at 500 points per plot and 125 points per subplot and the average values were calculated (Farruggia et al., 2012). Sward height data were then used to assess the sward height heterogeneity by calculating: i) the coefficient of variation (CV) and ii) Pielou's equitability index (J, Pielou, 1975) on three height classes $(<7 \mathrm{~cm}$, between 7 and $25 \mathrm{~cm}$, and $>25 \mathrm{~cm}$, according to Dumont et al., 2007; adapted), calculated as follows:

$J=\frac{H^{\prime}}{\log _{2}(S)}$

where $\mathrm{H}^{\prime}$ is Shannon diversity index among the three height classes and $\mathrm{S}$ is the number of classes.

\subsubsection{Insect sampling}

Butterflies (true butterflies: Rhopalocera and burnet moths: Zygaenidae) and bumblebees (Apidae: Bombus) were recorded by a specialist (see Acknowledgements) using the 'Pollard walk' (Pollard and Yates, 1993) along 50-m by 5-m fixed transects, four per each CG and BR plot (one per BR subplot). The surveys were made between 11 a.m. and 3 p.m., under good weather conditions (temperature $>+15^{\circ} \mathrm{C}$, gentle wind, cloudless sky) and were repeated twice a year during the exclusion of subplot $D$ from grazing, at 2- or 3-week intervals between early July and early August (see Annex A in Supplementary material), corresponding with the peak of flight activity for most species.

Ground beetles (Coleoptera: Carabidae) were sampled once a year with 12 fixed pitfall traps per each CG and BR plot (three per BR subplot). The traps were filled with a solution of $2 / 3$ ethanol and $1 / 3$ water at the beginning of the trapping period in mid-July; the liquid was topped up every 3-4 days and the traps emptied after 15 days (see Annex A in Supplementary material).
Butterflies, bumblebees and ground beetles were counted and identified at species level, so that abundance and species richness were analysed at both plot and subplot scales.

\subsubsection{Herbage mass and animal performance}

The average weather conditions over the three year experiment period were compared to a 46-year climatic database. All records were registered by the Marcenat weather station.

Seasonal herbage mass changes were evaluated by cutting $0.5 \mathrm{~m}^{2}$-strips $(0.1 \times 5 \mathrm{~m})$ at ground level five times a year (see Annex A in Supplementary material), with eight samplings per CGand BR-cattle plots (two per BR-cattle subplot) and four per CGand BR-sheep plots (one per BR-sheep subplot). Herbage mass ( grams of dry matter, $\mathrm{g}_{\mathrm{DM}}$ ) was weighted by drying samples at $60^{\circ} \mathrm{C}$ for $48 \mathrm{~h}$ and then aggregating them to express herbage mass in $\mathrm{t}_{\mathrm{DM}} \mathrm{ha}^{-1}$.

Animal performance was assessed recording live weight and body condition score (BCS; DEFRA, 2011; Russel et al., 1969) for each animal in five periods (see Annex A in Supplementary material).

\subsection{Data analysis}

Plant communities were classified by two hierarchical cluster analyses, for plots and BR subplots separately, using the PAST version 3.11 (Hammer et al., 2001). The similarity matrix was calculated using the Euclidean distance, whilst the complete linkage was selected as agglomeration method. Moreover, the homogeneity of Shannon diversity index and of the relative abundance of plant species pollinated by butterflies and bumblebees between grazing systems, grazer species and among subplots was verified at the set-up of the experiment performing a mixed model (SAS Inst. Inc., Cary, NC, USA).

Two mixed models were used to analyse any differences in flower cover, sward height and heterogeneity (i.e. CV and Pielou's equitability index), and insect counts. The first one considered the plot as the statistical unit, the year as a random factor, and grazing system and grazer species and all possible interactions as fixed factors. The second one considered the subplot as the statistical unit, the year as a random factor, and grazer species and all possible interactions as fixed factors. When significant interactions were observed, mixed models were also performed to detect statistical differences amongst the factor combinations. Tukey's post-hoc tests were performed when significant differences amongst subplots were found.

The responses of insect species to treatments were analysed using redundancy analysis (RDA) in CANOCO version 4.5 (ter Braak and Smilauer, 2002). Insect data were arranged in species matrices, whilst the four treatments (two grazing systems $\times$ two grazer species) were considered to be the environmental categorical variables and coded as dummy variables. Mantel tests with 9999 permutations were used to calculate the correlations between insect taxa (butterfly, bumblebee, and ground beetle) and treatment matrices (PAST version 3.11). A third matrix including flower cover, sward height and sward heterogeneity (CV) was used as a supplementary matrix to evaluate the gradients associated with the two main axes of the ordination plots (ter Braak and Smilauer, 2002).

Herbage mass at plot scale was analysed at each sampling date, using a mixed model with year as a random factor and grazing system, grazer species and all possible interactions as fixed factors. In the BR system, herbage mass was also analysed at subplot scale at each sampling date by performing a mixed model with year as a random factor and subplot, grazing animal and all possible interactions as fixed factors. The same analyses were performed 
on cattle and sheep animal live weight and BCS at plot scale, but grazing animal was not considered to be a fixed factor.

\section{Results}

\subsection{Botanical composition, flower cover and sward structure}

The dominant plant species detected during vegetation surveys were Agrostis capillaris L. (18.7\%), Festuca nigrescens Lam. (13.0\%) and Trifolium repens L. (6.1\%). The hierarchical cluster analyses showed ordinations without clear plot or subplot agglomerations based on grazing system or grazer species (see Annex $C$ in Supplementary material). At the experiment set-up, the Shannon diversity index (average value: 4.5 ) and the relative abundance of species pollinated by butterflies (15.0\%) and bumblebees (35.7\%) did not significantly differ between CG and BR, cattle and sheep plots, or among BR subplots.

Over the three year study period, the percentage of the flower cover was significantly higher in BR than in CG, in cattle than in sheep plots, and in D than A, B, and C subplots (Fig. 1). Moreover, positive interactions between grazing system and grazer species $(\mathrm{P}<0.05)$ and between year and grazer species $(\mathrm{P}<0.001)$ were observed, highlighting a significantly higher flower cover in BRthan in CG-sheep plots (Fig. 1a') as well as in cattle over sheep plots in 2012 and 2013 (Fig. 1a"). The average sward height was $24.1 \mathrm{~cm}$ and no differences between CG and BR plots, cattle and sheep plots, or among BR subplots were detected (Fig. 2a and b). Sward heterogeneity ( $\mathrm{CV}$ and Pielou's equitability index) was comparable between grazing system and grazer species and among BR subplots, except for the higher CV in cattle than in sheep plots (Fig. 2c and d).

\subsection{Insect abundance, diversity and response to treatments}

A total of 1913 butterflies from 37 different species were sampled during the experiment period. Only one protected species from European, national and regional lists was collected, i.e. Maculinea arion (Linnaeus 1758), which was only found in three cattle plots (two managed under BR and one under CG), whilst nine species were classified as 'locally rare' according to Bachelard and Fournier's (2008) abundance scale. There were three most abundant species over the three year period, namely Zygaena purpuralis (Brünnich 1763, 504 individuals, 26\% of the total), Thymelicus lineola (Ochsenheimer 1808, 404, 21\%) and Coenonympha pamphilus (Linnaeus 1758, 275, 14\%). Butterfly abundance and species richness were significantly higher in BR than in CG, in cattle than in sheep plots and in D than A, B and C subplots (Fig. 3a-d).

Bumblebee abundance amounted to 253 individuals, belonging to eight ground-nesting species (Benton, 2006; Goulson, 2010), namely Bombus hortorum (Linnaeus 1761), Bombus lapidarius (Linnaeus 1758), Bombus lucorum (Linnaeus 1761), Bombus pascuorum (Scopoli 1763), Bombus ruderarius (Muller 1776), Bombus soroeensis (Fabricius 1777), Bombus sylvarum (Linnaeus 1761), and Bombus terrestris (Linnaeus 1758). No protected species from national or European list species were found. The most abundant species were $B$. terrestris (137 individuals, $54 \%$ of the total) and B. lapidarius (76, 30\%). Bumblebee abundance and species richness was significantly higher in BR than in CG, in cattle than in sheep plots, and in D than A, B, and C subplots (Fig. 3e-h). Moreover, significant interactions between subplot and grazer species were detected for both bumblebee abundance $(\mathrm{P}<0.001)$ and species richness $(P<0.05)$, with the highest values in $D$ subplots for both cattle and sheep plots (Fig. $3 f^{\prime}$ and h').

A total of 4672 ground beetles, belonging to 22 species, was collected. Neither rare nor protected species from national or regional list species were found. The most abundant species were

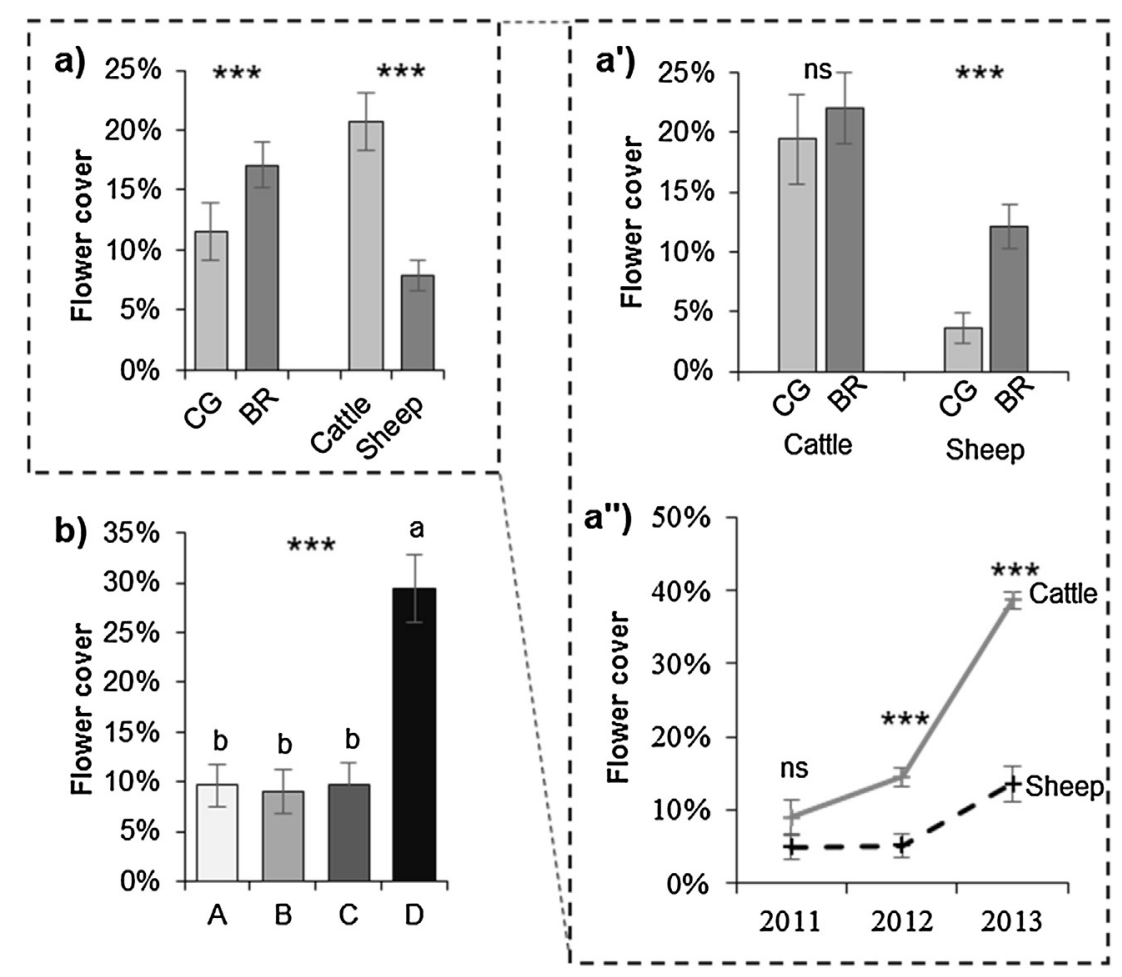

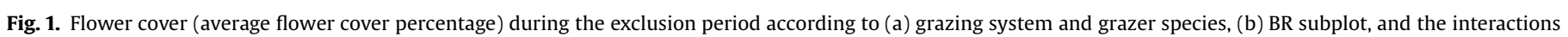

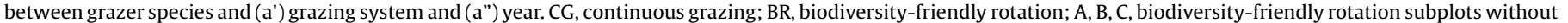

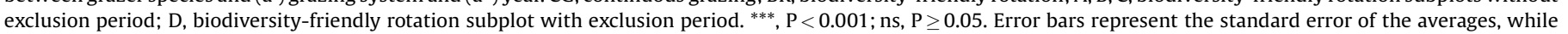
letters above histograms indicate significant differences among BR subplots according to Tukey's test. Number of replicates (per year) $=36$. 

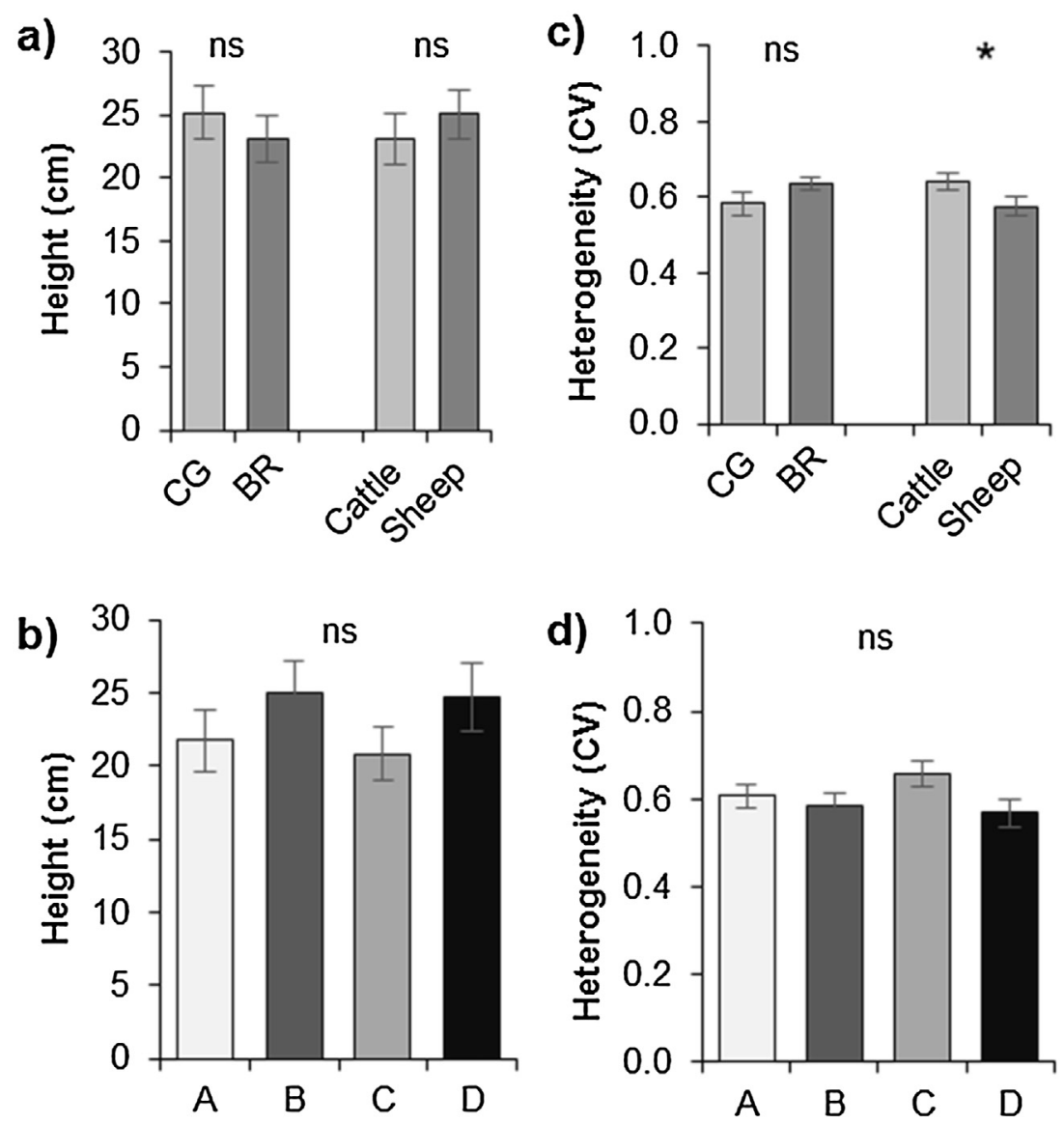

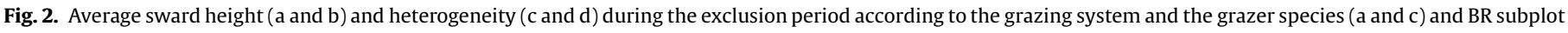

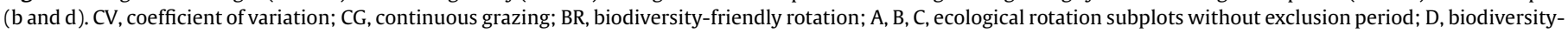
friendly rotation subplot with exclusion period. *, $\mathrm{P}<0.05$; ns, $\mathrm{P}>0.1$. Error bars represent the standard error of the averages. Number of replicates (per year) $=18$.

Carabus monilis Fabricius 1762 (1101 individuals, 24\%), C. violaceus Linne 1758 (1087, 23\%), Pterostichus melanarius (Illiger 1798, 937, 20\%) and Amara lunicollis Schiodte 1837 (585, 13\%). Ground beetle abundance and species richness did not differ between grazing systems, grazer species, or among subplots, as reported in Fig. $3 i-1$.

Mantel's tests, performed before the RDA, showed significant correlations between treatment matrix with butterfly $(\mathrm{r}: 0.18$; $\mathrm{P}<0.05)$ and bumblebee matrices $(\mathrm{r}: 0.39 ; \mathrm{P}<0.001)$ but not with ground beetle matrix. Thus, only butterfly and bumblebee matrices were retained and assembled in a unique flower-visiting insect matrix to explore the response of these two insect groups simultaneously. The latter matrix was still correlated with treatment matrix $(\mathrm{r}: 0.19 ; \mathrm{P}<0.05)$ and was used to perform the RDA analysis. The RDA ordination biplot, shown in Fig. 4, allows the visualisation of the first two axes, explaining $54.9 \%$ and $3.5 \%$ of the distribution, respectively. The ordination biplot showed a clear distinction among the four treatments, highlighting that the interaction between grazing system and grazer species affected butterfly and bumblebee species. The BR-cattle treatment separated well on the first axis, in contrast to CG- and BR-sheep treatments. The highest number of insect species was related to BR-cattle treatment, with 30 species (66.7\% of total butterfly and bumblebee species) displaying positive scores of the perpendicular projection onto this treatment vector (ter Braak and Smilauer, 2002). Noteworthy is the fact that among them there were the only endangered butterfly species (M. arion) and $89 \%$ of the 'locally rare' butterfly species, i.e. Adscita geryon (Hübner 1813), Mellicta parthenoides Keferstein 1851, M. arion, Pyrgus alveus (Hübner
1803), P. carthami (Hübner 1813), P. malvae (Linnaeus 1758), Spialia sertorius (Hoffmannsegg 1804), and Z. purpuralis (Brünnich 1763). This treatment and the related insect species fitted with high flower cover percentages, low sward height and high sward heterogeneity. In contrast, insect species clearly fitting with other treatments accounted for fewer individuals (see Annex D in Supplementary material for the complete species-abundance report). Moreover, according to Bachelard and Fournier (2008), the three species associated with CG-sheep treatments, i.e. Aricia agestis (Denis and Sciffermüler, 1775), Colias hyale (Linnaeus 1758), and Gonepteryx rhamni (Linnaeus 1758), were very common species, locally frequenting a range of habitats and were found in small numbers (one, one, and three, respectively). The butterfly species Plebejus idas (Linnaeus 1761), reported as 'locally rare', though related to BR-sheep treatment, was found only once. The CG-cattle treatment showed the weakest relationship with species, as indicated by its short arrow on the biplot (ter Braak and Smilauer, 2002). Three species, namely Cyaniris semiargus (Rottemburg 1775), Ochlodes venatus (Bremer and Grey, 1853) and B. hortorum, were strongly related to this treatment, as they were exclusively collected in CG-cattle plots over the three years, even if with only a few individuals (two, one and three, respectively).

\subsection{Herbage mass and animal performance}

The study area was characterised in 2011 and 2012 by lower precipitation $(-100$ and $-86 \mathrm{~mm})$ and higher temperatures $(+1.3$ 


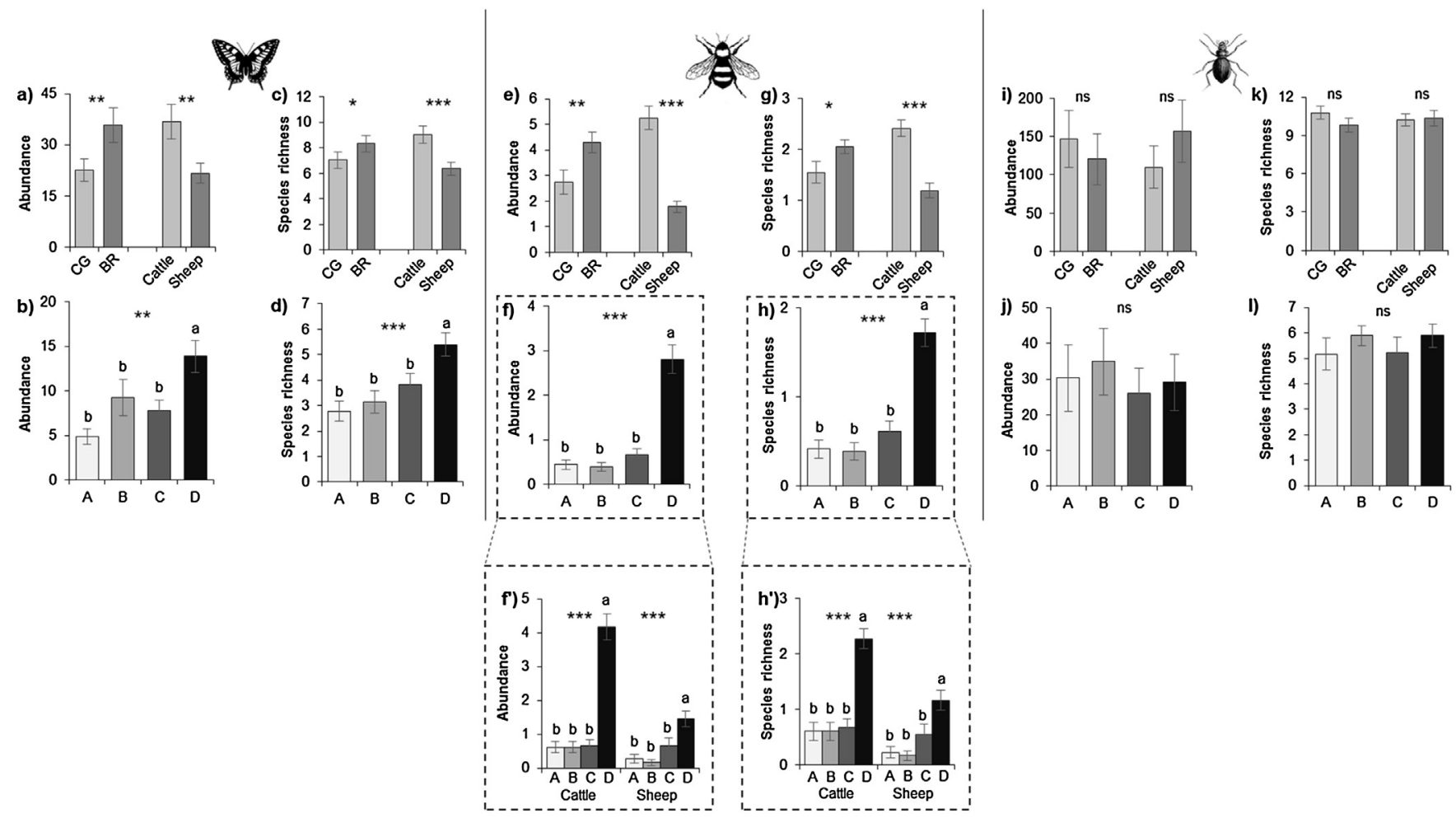

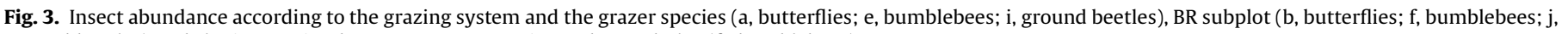
ground beetles) and the interaction between grazer species and BR subplot ( $\mathrm{f}^{\prime}$, bumblebees).

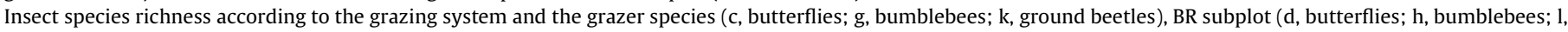

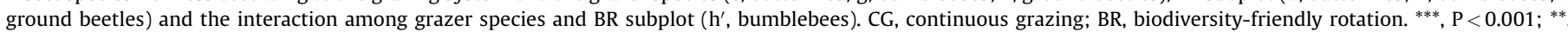

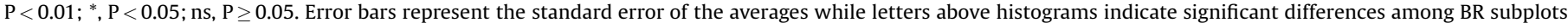
according to Tukey's test. Number of replicates $=36$ (butterflies and bumblebees) and 18 (ground beetles).

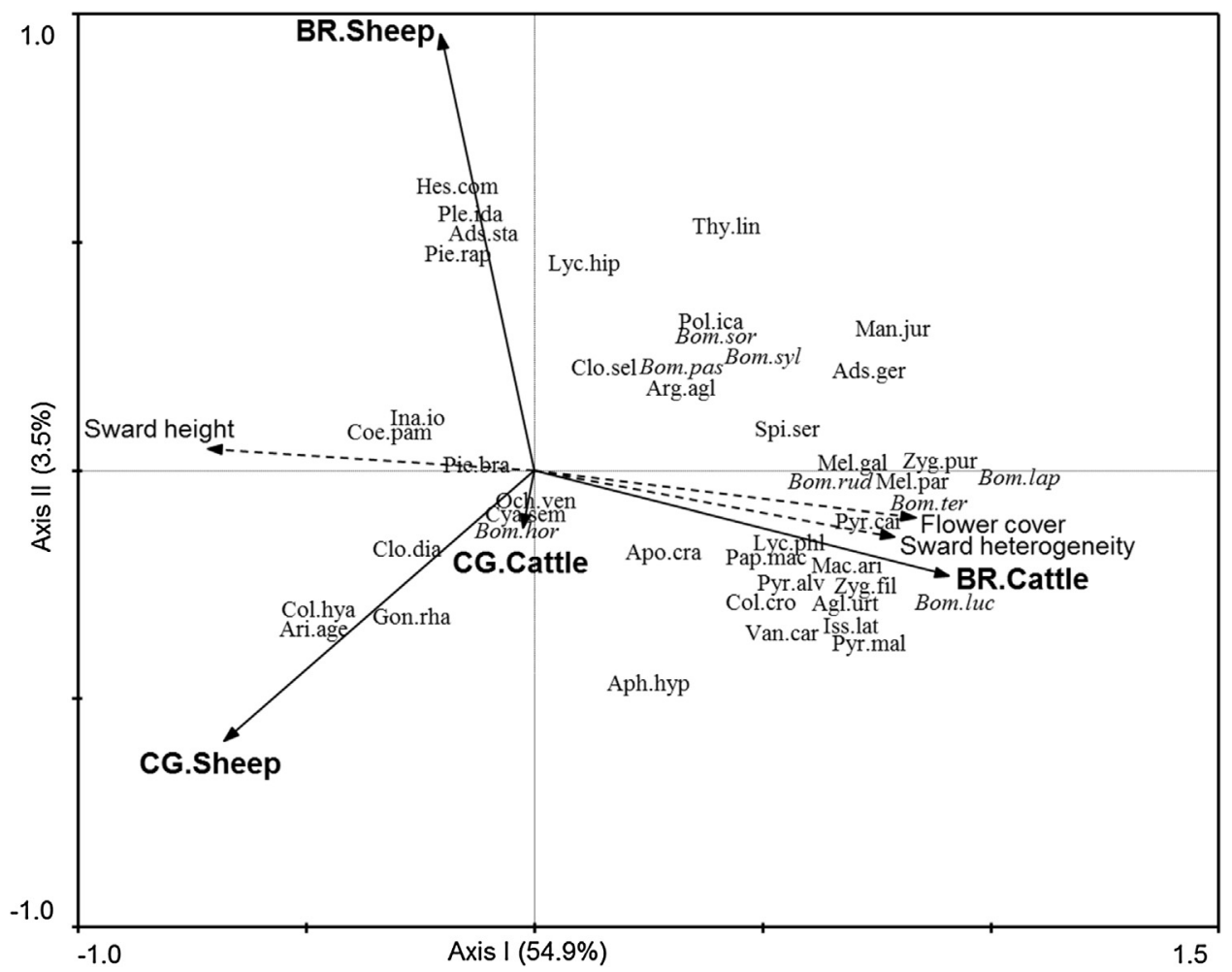

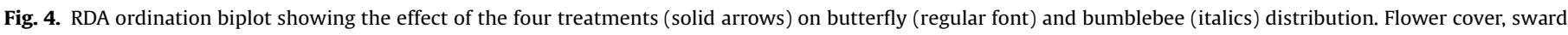

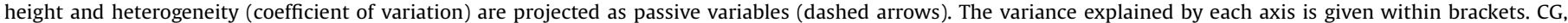
continuous grazing; BR, biodiversity-friendly rotation; for insect species abbreviations see Annex D in Supplementary material. 
and $\left.+0.4^{\circ} \mathrm{C}\right)$, whilst in 2013 by higher precipitation $(+162 \mathrm{~mm})$ and lower temperatures $\left(-0.3^{\circ} \mathrm{C}\right)$ compared to $1965-2010$.

Starting and ending dates of grazing periods were set according to herbage availability, weather conditions and traditional habits of the local farmers. Consequently, cattle and sheep started grazing on May 18th, 2011, May 23rd, 2012 and on June 5th, 2013, whilst they finished on October 4th, 2011, on October 9th, 2012 and on October 22th, 2013, accounting for 140 grazing days per year.

The average annual herbage mass amounted to $2.93 \mathrm{t}_{\mathrm{DM}} \mathrm{ha}^{-1}$ and did not differ between CG and BR (Fig. 5a) or among subplots throughout the whole grazing season. Conversely, it was significantly lower in cattle than in sheep plots, except at the beginning of the grazing season (Fig. 5b). Nevertheless, herbage mass was always comparable when the interaction between the grazing system and grazer species was considered (Fig. 5c).

No differences in animal live weights were recorded, except for the higher weight of sheep under CG in July, whereas BCS was always comparable along the grazing season for both cattle and sheep (Figs. 6 and 7).
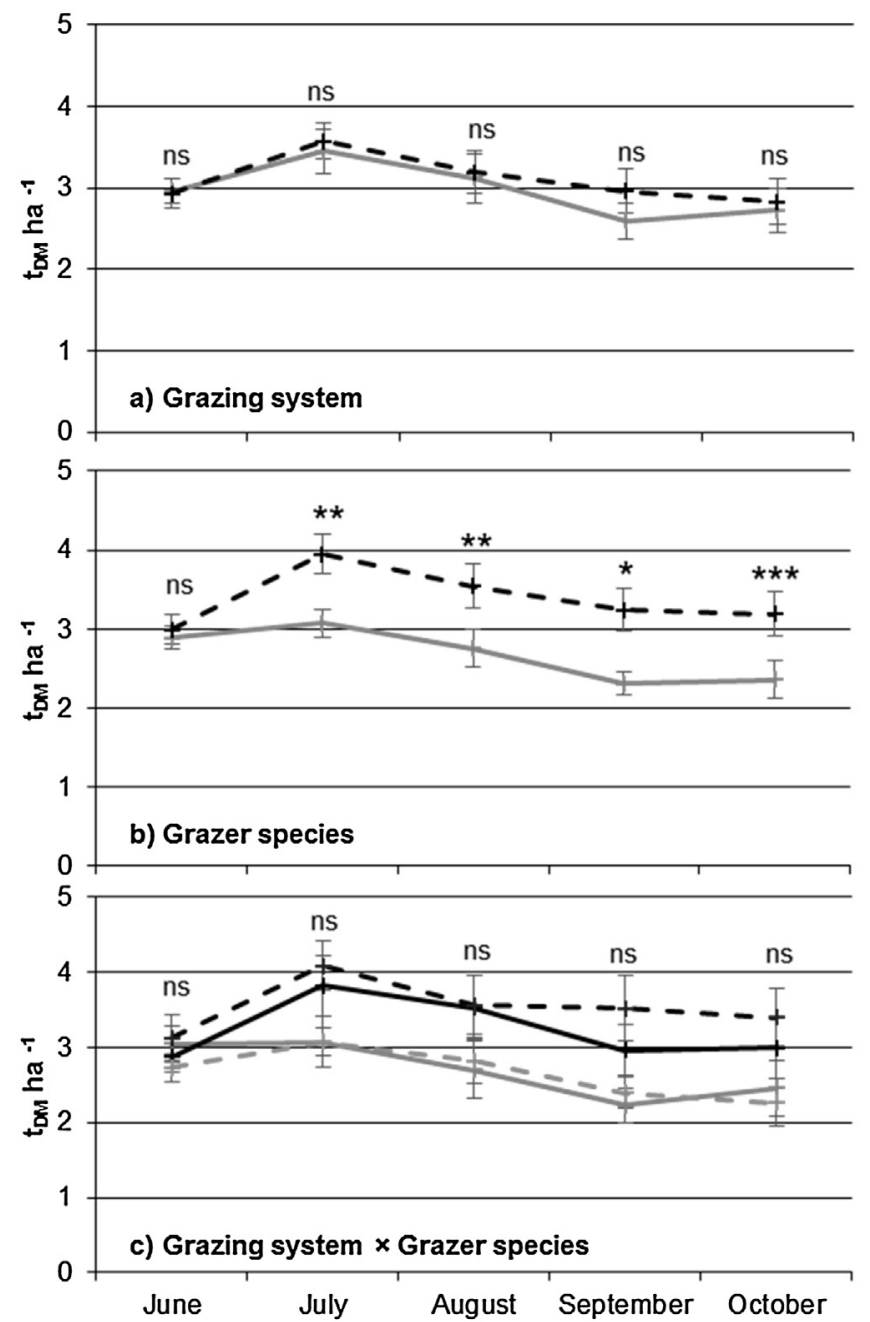

Fig. 5. Herbage mass during the grazing season according to (a) the grazing system (grey solid line represents continuous grazing - CG - and black dashed line biodiversity-friendly rotation - BR), (b) the grazer species (grey solid line represents cattle and black dashed line sheep) and (c) the grazing system $\times$ the grazer species (grey solid line represents CG-cattle, grey dashed line BR-cattle, black solid lines CG-sheep, black dashed line BR-sheep). DM, dry matter based. ***, $\mathrm{P}<0.001$; ${ }^{* *}, \mathrm{P}<0.01 ;{ }^{*}, \mathrm{P}<0.05 ; \mathrm{ns}, \mathrm{P} \geq 0.05$. Error bars represent the standard error of the averages. Number of replicates $=18$ (grazing system and grazer species) and 9 (grazing system $\times$ grazer species).
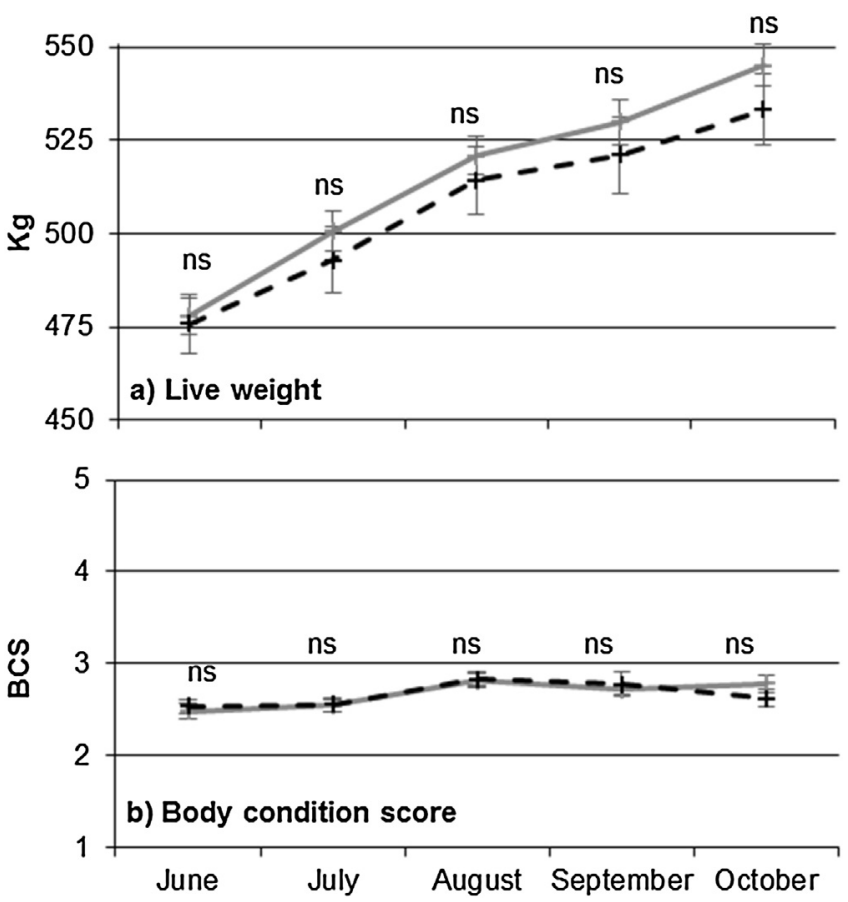

Fig. 6. Cattle performance during the grazing season in terms of (a) animal live weight and (b) body condition score (BCS); grey solid line represents continuous grazing and black dashed line biodiversity-friendly rotation. $n s, P \geq 0.05$. Error bars represent the standard error of the averages. Number of replicates (per date) $=63$.

\section{Discussion}

The present study evidenced the beneficial effects produced by the implementation of a biodiversity-friendly rotational grazing system, which led to an increase in butterfly and bumblebee abundance and diversity, whilst, at the same time, meeting animal
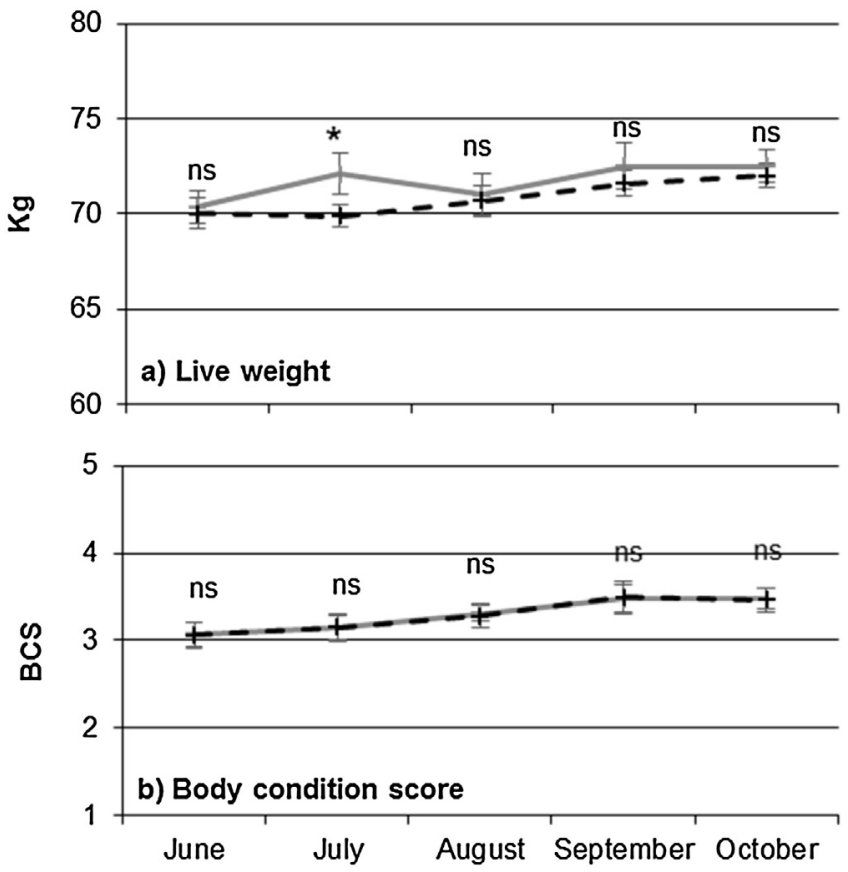

Fig. 7. Sheep performance during the grazing season in terms of (a) animal live weight and (b) body condition score (BCS); grey solid line represents continuous grazing and black dashed line biodiversity-friendly rotation. ${ }^{*}, \mathrm{P}<0.05 ; \mathrm{ns}, \mathrm{P} \geq 0.05$. Error bars represent the standard error of the averages. Number of replicates $=63$. 
and grassland production objectives. These noteworthy findings likely resulted from the combination of appropriate stocking rate and length of the grazing exclusion period. Both butterfly and bumblebee abundance and diversity showed similar responses to treatments, as both taxa were attracted in D subplots by the temporary increase in resource availability and lack of livestock disturbances, such as grazing and trampling. Moreover, the excluded area may have represented a suitable nesting place for bumblebees (since all species were ground-nesting) as well as for egg-laying and larval development for butterflies during the twomonth exclusion period. The experiment confirmed that flower cover (mainly forbs and legumes) was strongly affected by grazer species, due to specific intake behaviour, with sheep preferring forbs and legumes and flowering plant parts, whilst cattle are less selective (Dumont et al., 2011; Sharp et al., 2012). Moreover, the positive interaction found between year and grazer species might indicate that the lower selection for legumes, forbs and flowers by cattle may enhance the overall flower cover, above all in years with favourable weather conditions (e.g. in 2013). Conversely, the BR system in sheep grazed plots allowed for a temporary increase in flower cover, which was, however, insufficient to reach cattle grazed plot levels. The positive effects on insect assemblages were only ascribable to the grazing system applied regardless of grazer species, highlighting that the improvement in insect abundance and diversity can be determined by the implementation of the BR regime or by cattle grazing, independently. However, the multivariate analysis on flower-visiting species evidenced that most of them (including almost all the endangered and locally rare species) were supported by the BR-cattle treatment, due to high flower cover and sward heterogeneity, as suggested by the socalled 'trophic level' hypothesis (Kruess and Tscharntke, 2002; Öckinger et al., 2006). Nevertheless, since a few different species were advantaged by other treatments (e.g. B. hortorum by CG-cattle treatment and Pieris rapae (Linnaeus 1758) by BR-sheep treatment), a mosaic of management strategies would be likely to increase flower-visiting insect diversity on a wider scale, as well as other insect taxa diversity (e.g. ants, van Noordwijk et al., 2012). However, so as to obtain better understanding of butterfly assemblages in further research it would be important to assess also the effects of grazing treatments on the abundance of host plants, which are needed for butterfly spawning and larvae feeding, i.e. to complete their life cycle (Dennis et al., 1997). Moreover, the effect of the BR system on insect assemblages should also be examined at the end of the growing season, as D subplots may turn into an 'ecological trap' (Shochat et al., 2005) when regrazed after the exclusion period. Indeed, although the subplots which were not grazed during the main flowering period did attract adult insects, their eggs and larvae or nests might later have suffered from livestock disturbances in August. Thus, it would be important to discriminate if the observed increase in flowervisiting insect abundance and diversity only constituted a temporary concentration of adults (the so-called 'concentration effect') and not a real and sustained population-level effect (Kleijn et al., 2011; Scheper et al., 2015). A longer monitoring period across years would allow to disentangle these effects by evaluating to what extent an increase in butterfly and bumblebee populations occurs in the long-term, whereas the non significant interactions among treatments and years suggested a concentration effect over the timespan considered. However, an annual increase in both abundance and biodiversity of flower-visiting insects, even if limited to the two-month exclusion period, still can enhance the level of ecosystem services provided, such as pollination.

Unexpectedly, the average sward height was not affected by the grazing system, maybe due to the relatively high stocking rate applied and the homogeneity of grassland composition and distribution, which determined a homogeneous exploitation by livestock under both systems. This result was also confirmed by the lack of differences in sward heterogeneity between BR and CG and among BR subplots. Consequently, grassland structural homogeneity may have determined the lack of effects in ground beetle assemblages, since these taxa are markedly affected by grassland heterogeneity (e.g., Batáry et al., 2007).

The differences in herbage mass levels observed between cattle and sheep grazing from July onwards was an unforeseen result, as stocking rate was comparable between cattle and sheep at the beginning of each year. However, the cattle stocking rate involved heifers, that increased their live weight during each grazing season (on average $+58 \mathrm{~kg},+12 \%$ ), whilst the sheep stocking rate involved dry ewes, that had a much more stable live weight (on average + $1.5 \mathrm{~kg},+2 \%$ ). This is why herbage intake and mass could have been partly affected by different live weight gains. Nevertheless, the interaction between the grazer species and the grazing system was not significant for herbage mass, which was comparable between CG and BR. Studies carried out in other biogeographic areas and environments did not detect differences in herbage mass when CG was compared to rotational grazing systems (Briske et al., 2003; Deregibus et al., 2007; Dowling et al., 2005; Pulido and Leaver, 2003; Wang et al., 2009). Even if in the CG animal live weight was higher in the mid-grazing season for sheep, differences in terms of kilograms were negligible, as they were less than $3.5 \%$ of the live weight. Moreover, the BCS on the same recording date was not affected by these small variations in animal live weight. Similarly, recent studies carried out in European mountain semi-natural grasslands reported comparable outputs in animal performance between CG and rotational grazing systems (Farruggia et al., 2014; Stejskalová et al., 2013). Thus, not only did the BR system provide remarkable results as to flower-visiting insects, but it also maintained animal production levels, ensuring unvaried economic returns for farmers, whilst, at the same time, enhancing ecosystem diversity. Moreover, the implementation of a BR system is not only biologically but also economically sustainable, as it requires limited additional costs and work for the farmers, who have to fence the subplots about twice a month.

Grazing exclusion repeated several years over the same area could affect plant species competition, vegetation dynamics, leading to change in species relative abundance, with cascade effects on insect communities, herbage mass and animal performance (Davis et al., 2014). Therefore, so as to allow for a homogeneous distribution of the benefits of BR over the whole grazed area, it might well be advisable to implement a rotation of the grazing exclusion area amongst the four BR subplots.

\section{Conclusions}

The present study demonstrated the effectiveness of the innovative 'biodiversity-friendly rotational' grazing system for the enhancement of flower-visiting insect abundance and diversity in semi-natural grassland environments, when compared to a continuous grazing system. The beneficial effects on butterflies and bumblebees from grazing exclusion of one quarter of the BR enclosures for two months during the flowering peak (June to July) were more remarkable under cattle than sheep grazing. Moreover, most flower-visiting species, including rare species, were positively influenced by the BR-cattle treatment, as they were attracted by its high flower cover and sward heterogeneity. Conversely, the BR grazing system was not effective in enhancing ground beetle assemblages. Neither herbage mass nor animal performance were negatively affected by the BR system, confirming the promising opportunities offered by this innovative grazing system to maintain the economic returns for farmers whilst enhancing ecosystem diversity. However, additional research on the type and extent of the effects of the 'biodiversity-friendly rotational' grazing 
system on insect assemblages, botanical composition, herbage mass, and animal performance in the long-term appears warranted.

\section{Acknowledgments}

This research was funded by the European Community's 7th Framework Program under the grant agreement FP7-244983 Multisward. The authors thank the staff of the Herbipôle experimental farm for their technical assistance. They are also grateful to Benjamin Calmont and Philippe Bachelard from the Societé d'histoire naturelle Alcide-d'Orbigny for monitoring insect diversity, to Michel Frain for monitoring botanical diversity, and to Monica Vercelli from the University of Torino for her helpful suggestions on bumblebee ecology. A thank you also to Barbara Wade for her linguistic advice. A special thanks goes to the reviewers for their detailed comments and useful suggestions to improve the statistical analyses and the manuscript.

\section{Appendix A. Supplementary data}

Supplementary data associated with this article can be found, in the online version, at http://dx.doi.org/10.1016/j.agee.2017.02.030.

\section{References}

Öckinger, E., Eriksson, A.K., Smith, H.G., 2006. Effects of grassland abandonment, restoration and management on butterflies and vascular plants. Biol. Conserv. 133, 291-300. doi:http://dx.doi.org/10.1016/j.biocon.2006.06.009.

Agnoletti, M., 2014. Rural landscape, nature conservation and culture: some notes on research trends and management approaches from a (southern) European perspective. Landsc. Urban Plan. 126, 66-73. doi:http://dx.doi.org/10.1016/j. landurbplan.2014.02.012.

Altieri, M.A., 2002. Agroecology: the science of natural resource management for poor farmers in marginal environments. Agric. Ecosyst. Environ. 93, 1-24. doi: http://dx.doi.org/10.1016/S0167-8809(02)00085-3.

Báldi, A., Batáry, P., Kleijn, D., 2013. Effects of grazing and biogeographic regions on grassland biodiversity in Hungary -analysing assemblages of 1200 species. Agric. Ecosyst. Environ. Landsc. Ecol. Biodivers. Agric. Landsc. 166, 28-34. doi http://dx.doi.org/10.1016/j.agee.2012.03.005.

Bachelard, P., Fournier, F., 2008. Papillons Du Puy-de-Dôme: Atlas écologique Des Rhopalocères Et Zygènes. Editions Revoir, Nohanent, France.

Barthram, G.T., 1984. Experimental techniques: the HFRO sward stick. Bienn. Rep. $1985,29-30$

Batáry, P., Báldi, A., Szél, G., Podlussány, A., Rozner, I., Erdős, S., 2007. Responses of grassland specialist and generalist beetles to management and landscape complexity. Divers. Distrib. 13, 196-202. doi:http://dx.doi.org/10.1111/j.14724642.2006.00309.x.

Benton, T., 2006. Bumblebees. HarperCollins, London, UK.

Bernués, A., Ruiz, R., Olaizola, A., Villalba, D., Casasús, I., 2011. Sustainability of pasture-based livestock farming systems in the European Mediterranean context: synergies and trade-offs. Livest. Sci. Spec. Issue: Assess. Sustainable Dev. Anim. Prod. Syst. 139, 44-57. doi:http://dx.doi.org/10.1016/j. livsci.2011.03.018.

Braun-Blanquet, J., Fuller, G.D., Conard, H.S., 1932. Plant Sociology; the Study of Plant Communities. McGraw-Hill book company inc, New York and London.

Briske, D.D., Fuhlendorf, S.D., Smeins, F.E., 2003. Vegetation dynamics on rangelands: a critique of the current paradigms. J. Appl. Ecol. 40, 601-614. doi: http://dx.doi.org/10.1046/j.1365-2664.2003.00837.x.

Brym, Z.T., Reeve, J.R., 2016. Agroecological principles from a bibliographic analysis of the term agroecology. In: Lichtfouse, E. (Ed.), Sustainable Agriculture Reviews, Sustainable Agriculture Reviews. Springer International Publishing, pp. 203-231. doi:http://dx.doi.org/10.1007/978-3-319-26777-7 5.

Caballero, R., 2015. Transition pathways to sustainable pastoral systems in europe. Open Agric. J. 9, 6-20. doi:http://dx.doi.org/10.2174/1874331501509010006.

Cameron, K.H., Leather, S.R., 2012. How good are carabid beetles (Coleoptera, Carabidae) as indicators of invertebrate abundance and order richness? Biodivers. Conserv. 21, 763-779. doi:http://dx.doi.org/10.1007/s10531-0110215-9.

Cingolani, A.M., Noy-Meir, I., Díaz, S., 2005. Grazing effects on rangeland diversity: synthesis of contemporary models. Ecol. Appl. 15, 757-773. doi:http://dx.doi. org/10.1890/03-5272.

Climate-Data.org, 2016. Climate: Clermont-Ferrand - Climatic Graph, Temperature Graph, Climatic Table - Climate-Data.org. [WWW Document]. Clim.-Data. URL http://en.climate-data.org/location/336/ (Accessed 5.19.16).

Craheix, D., Angevin, F., Doré, T., de Tourdonnet, S., 2016. Using a multicriteria assessment model to evaluate the sustainability of conservation agriculture at the cropping system level in France. Eur. J. Agron. 76, 75-86. doi:http://dx.doi. org/10.1016/j.eja.2016.02.002.

DEFRA, 2011. Condition Scoring of Dairy Cows. Department for Environment, Food \& Rural Affairs, London.

Davis, S.C., Burkle, L.A., Cross, W.F., Cutting, K.A., 2014. The effects of timing of grazing on plant and arthropod communities in high-elevation grasslands. PLoS One 9, e110460. doi:http://dx.doi.org/10.1371/journal.pone.0110460.

Dengler, J., Janišová, M., Török, P., Wellstein, C., 2014. Biodiversity of Palaearctic grasslands: a synthesis. Agric. Ecosyst. Environ. 182,1-14. doi:http://dx.doi.org/ 10.1016/j.agee.2013.12.015.

Dennis, P., Young, M.R., Howard, C.L., Gordon, IJ., 1997. The response of epigeal beetles (Col.: carabidae, staphylinidae) to varied grazing regimes on Upland nardus stricta grasslands. J. Appl. Ecol. 34, 433-443. doi:http://dx.doi.org/ $10.2307 / 2404888$

Deregibus, V.A., Jacobo, E., Rodriguez, A., 2007. Improvement in rangeland condition of the Flooding Pampa of Argentina through controlled grazing. Afr. J. Range Forage Sci. 12, 92-96. doi:http://dx.doi.org/10.1080/10220119.1995.9647873.

Dong, S., Wen, L, Liu, S., Zhang, X., Lassoie, J.P., Yi, S., Li, X., Li, J. Li, Y, 2011. Vulnerability of worldwide pastoralism to global changes and interdisciplinary strategies for sustainable pastoralism. Ecol. Soc. 16.

Dowling, P.M., Kemp, D.R., Ball, P.D., Langford, C.M., Michalk, D.L., Millar, G.D., Simpson, P.C., Thompson, R.P., 2005. Effect of continuous and time-control grazing on grassland components in south-eastern Australia. Aust. J. Exp. Agric. 45, 369-382. doi:http://dx.doi.org/10.1071/EA03104.

Dumont, B., Garel, J.P., Ginane, C., Decuq, F., Farruggia, A., Pradel, P., Rigolot, C., Petit, M., 2007. Effect of cattle grazing a species-rich mountain pasture under different stocking rates on the dynamics of diet selection and sward structure. Animal 1, 1042-1052. doi:http://dx.doi.org/10.1017/S1751731107000250.

Dumont, B., Farruggia, A., Garel, J.-P., Bachelard, P., Boitier, E., Frain, M., 2009. How does grazing intensity influence the diversity of plants and insects in a speciesrich upland grassland on basalt soils? Grass Forage Sci. 64, 92-105. doi:http:// dx.doi.org/10.1111/j.1365-2494.2008.00674.x.

Dumont, B., Carrère, P., Ginane, C., Farruggia, A., Lanore, L., Tardif, A., Decuq, F., Darsonville, O., Louault, F., 2011. Plant-herbivore interactions affect the initial direction of community changes in an ecosystem manipulation experiment. Basic Appl. Ecol. 12, 187-194. doi:http://dx.doi.org/10.1016/j.baae.2011.02.011.

Ewers, R.M., Didham, R.K., 2006. Confounding factors in the detection of species responses to habitat fragmentation. Biol. Rev. Camb. Philos. Soc. 81, 117-142. doi:http://dx.doi.org/10.1017/S1464793105006949.

Farruggia, A., Dumont, B., Scohier, A., Leroy, T., Pradel, P., Garel, J.-P., 2012. An alternative rotational stocking management designed to favour butterflies in permanent grasslands. Grass Forage Sci. 67, 136-149. doi:http://dx.doi.org/ 10.1111/j.1365-2494.2011.00829.x.

Farruggia, A., Pomiès, D., Coppa, M., Ferlay, A., Verdier-Metz, I., Le, M., Bethier, A., Pompanon, F., Troquier, O., Martin, B., 2014. Animal performances, pasture biodiversity and dairy product quality: how it works in contrasted mountain grazing systems. Agric. Ecosyst. Environ. 185, 231-244. doi:http://dx.doi.org/ 10.1016/j.agee.2014.01.001.

Ferrazzi, P., Vercelli, M., 2016. Flora apistica, In: Contessi, A. (Ed.), Le Api: Biologia, Allevamento, Prodotti. Fourth ed. Edagricole-New Business Media, Milano, pp. $147-178$.

Goulson, D., 2010. Bumblebees: Behaviour, Ecology, and Conservation. OUP, Oxford.

Grime, J.P., 1973. Competitive exclusion in herbaceous vegetation. Nature 242, 344347. doi:http://dx.doi.org/10.1038/242344a0.

Hammer, Ø., Harper, D.A.T., Ryan, P.D., 2001. PAST: paleontological statistics software package for education and data analysis. Palaeontol. Electron. 4, 1-9.

Iussig, G., Lonati, M., Probo, M., Hodge, S., Lombardi, G., 2015. Plant species selection by goats foraging on montane semi-natural grasslands and grazable forestlands in the Italian Alps. Ital. J. Anim. Sci. 14, 484-494. doi:http://dx.doi.org/10.4081/ ijas.2015.3907.

Kleijn, D., Rundlöf, M., Scheper, J., Smith, H.G., Tscharntke, T., 2011. Does conservation on farmland contribute to halting the biodiversity decline? Trends Ecol. Evol. 26, 474-481. doi:http://dx.doi.org/10.1016/j.tree.2011.05.009.

Kruess, A., Tscharntke, T., 2002. Contrasting responses of plant and insect diversity to variation in grazing intensity. Biol. Conserv. 106, 293-302. doi:http://dx.doi. org/10.1016/S0006-3207(01)00255-5.

Landolt, E., Bäumler, B., Erhardt, A., Hegg, O., Klotzli, F., Lammler, W., Nobis, M. Rudmann-Maurer, K., Schweingruber, F.H., Theurillat, J.-P., Urmi, E., Vust, M. Wohllgemuth, T., 2010. Flora Indicativa: ökologische Zeigerwerte Und Biologische Kennzeichen Zur Flora Der Schweiz Und Der Alpen=ecological Indicator Values and Biological Attributes of the Flora of Switzerland and the Alps. Editions des Conservatoire et Jardin botaniques de la Ville de Genève \& HauptVerlag, Bern, Stuttgart, Vienna.

Magurran, A.E., 1988. Ecological Diversity and Its Measurement. Princeton University Press, Princeton, NJ, USA.

Orlandi, S., Probo, M., Sitzia, T., Trentanovi, G., Garbarino, M., Lombardi, G., Lonati, M., 2016. Environmental and land use determinants of grassland patch diversity in the western and eastern Alps under agro-pastoral abandonment. Biodivers. Conserv. 25, 275-293. doi:http://dx.doi.org/10.1007/s10531-016-1046-5.

Phalan, B., Balmford, A., Green, R.E., Scharlemann, J.P.W., 2011. Minimising the harm to biodiversity of producing more food globally. Food Policy Challenge Global Food Sustainability 36 (Suppl. 1), S62-S71. doi:http://dx.doi.org/10.1016/j. foodpol.2010.11.008.

Pielou, E.C., 1975. Ecological diversity. Wiley InterScience. Wiley, New York, USA.

Pittarello, M., Probo, M., Lonati, M., Bailey, D.W., Lombardi, G., 2016a. Effects of traditional salt placement and strategically placed mineral mix supplements on 
cattle distribution in the Western Italian Alps. Grass Forage Sci. 71, 529-539. doi:http://dx.doi.org/10.1111/gfs.12196.

Pittarello, M., Probo, M., Lonati, M., Lombardi, G., 2016b. Restoration of sub-alpine shrub-encroached grasslands through pastoral practices: effects on vegetation structure and botanical composition. Appl. Veg. Sci. 19, 381-390. doi:http://dx. doi.org/10.1111/avsc.12222.

Pollard, E., Yates, T.J., 1993. Monitoring Butterflies for Ecology and Conservation. Chapman and Hall, London.

Probo, M., Lonati, M., Pittarello, M., Bailey, D.W., Garbarino, M., Gorlier, A., Lombardi, G., 2014. Implementation of a rotational grazing system with large paddocks changes the distribution of grazing cattle in the south-western Italian Alps. Rangel. J. 36, 445-458. doi:http://dx.doi.org/10.1071/RJ14043.

Pulido, R.G., Leaver, J.D., 2003. Continuous and rotational grazing of dairy cows - the interactions of grazing system with level of milk yield, sward height and concentrate level. Grass Forage Sci. 58, 265-275. doi:http://dx.doi.org/10.1046/ j.1365-2494.2003.00378.x.

Rey, F., Dutoit, T., Cote, F., Lescourret, F., 2015. L'ingénierie écologique au service de l'aménagement du territoire - Avant-propos. Sci. Eaux Territ. Rev. Irstea 16, 2-3.

Russel, A.J.F., Doney, J.M., Gunn, R.G., 1969. Subjective assessment of body fat in live sheep. J. Agric. Sci. 72, 451-454. doi:http://dx.doi.org/10.1017/ S0021859600024874.

Söderström, B., Svensson, B., Vessby, K., Glimskär, A., 2001. Plants, insects and birds in semi-natural pastures in relation to local habitat and landscape factors. Biodivers. Conserv. 10, 1839-1863. doi:http://dx.doi.org/10.1023/ A: 1013153427422

Savian, J.V., Neto, A.B., de David, D.B., Bremm, C., Schons, R.M.T., Genro, T.C.M., do Amaral, G.A., Gere, J., McManus, C.M., Bayer, C., de Faccio Carvalho, P.C., 2014. Grazing intensity and stocking methods on animal production and methane emission by grazing sheep: implications for integrated crop-livestock system. Agric. Ecosyst. Environ. 190, 112-119. doi:http://dx.doi.org/10.1016/j. agee.2014.02.008.

Scheper, J., Bommarco, R., Holzschuh, A., Potts, S.G., Riedinger, V., Roberts, S.P.M., Rundlöf, M., Smith, H.G., Steffan-Dewenter, I., Wickens, J.B., Wickens, V.J., Kleijn, D., 2015. Local and landscape-level floral resources explain effects of wildflower strips on wild bees across four European countries. J. Appl. Ecol. 52, 1165-1175. doi:http://dx.doi.org/10.1111/1365-2664.12479.

Scohier, A., Dumont, B., 2012. How do sheep affect plant communities and arthropod populations in temperate grasslands? Animal 6, 1129-1138. doi: http://dx.doi.org/10.1017/s1751731111002618.

Scohier, A., Ouin, A., Farruggia, A., Dumont, B., 2012. Is there a benefit of excluding sheep from pastures at flowering peak on flower-visiting insect diversity? J. Insect Conserv. 17, 287-294. doi:http://dx.doi.org/10.1007/s10841-012-9509-9.

Seppelt, R., Voinov, A., 2002. Optimization methodology for land use patterns using spatially explicit landscape models. Ecol. Model.151,125-142. doi:http://dx.doi. org/10.1016/S0304-3800(01)00455-0.

Sharp, J.M., Edwards, G.R., Jeger, M.J., 2012. Impact of the spatial scale of grasslegume mixtures on sheep grazing behaviour, preference and intake, and subsequent effects on pasture. Animal 6, 1848-1856. doi:http://dx.doi.org/ $10.1017 / \mathrm{s} 1751731112000729$.

Shochat, E., Patten, M.A., Morris, D.W., Reinking, D.L., Wolfe, D.H., Sherrod, S.K., Lindström, J., 2005. Ecological traps in isodars: effects of tallgrass prairie management on bird nest success. Oikos 111, 159-169. doi:http://dx.doi.org/ 10.1111/j.0030-1299.2005.13907.x.

Sjödin, N.E., Bengtsson, J., Ekbom, B., 2008. The influence of grazing intensity and landscape composition on the diversity and abundance of flower-visiting insects. J. Appl. Ecol. 45, 763-772. doi:http://dx.doi.org/10.1111/j.13652664.2007.01443.x.

Soussana, J.-F., Tichit, M., Lecompte, P., Dumont, B., 2014. Agroecology: integration with livestock. Proceedings of the FAO International Symposium: Agroecology for Food Security and Nutrition, 18-19 September 2014, Rome, Italy.

Stejskalová, M., Hejcmanová, P., Pavlù, V., Hejcman, M., 2013. Grazing behavior and performance of beef cattle as a function of sward structure and herbage quality under rotational and continuous stocking on species-rich upland pasture. Anim. Sci. J. 84, 622-629. doi:http://dx.doi.org/10.1111/asj.12048.

Tasser, E., Tappeiner, U., 2005. New model to predict rooting in diverse plant community compositions. Ecol. Model. 185, 195-211. doi:http://dx.doi.org/ 10.1016/j.ecolmodel.2004.11.024.

Tilman, D., Cassman, K.G., Matson, P.A., Naylor, R., Polasky, S., 2002. Agricultural sustainability and intensive production practices. Nature 418, 671-677. doi: http://dx.doi.org/10.1038/nature01014.

Tocco, C., Probo, M., Lonati, M., Lombardi, G., Negro, M., Nervo, B., Rolando, A., Palestrini, C., 2013. Pastoral practices to reverse shrub encroachment of subAlpine grasslands: dung beetles (Coleoptera, scarabaeoidea) respond more quickly than vegetation. PLoS One 8, e83344. doi:http://dx.doi.org/10.1371/ journal.pone.0083344.

Wallis De Vries, M.F., Parkinson, A.E., Dulphy, J.P., Sayer, M., Diana, E., 2007. Effects of livestock breed and grazing intensity on biodiversity and production in grazing systems. 4. Effects on animal diversity. Grass Forage Sci. 62, 185-197. doi:http:// dx.doi.org/10.1111/j.1365-2494.2007.00568.x.

Wang, C.J., Tas, B.M., Glindemann, T., Mueller, K., Schiborra, A., Schoenbach, P., Gierus, M., Taube, F., Susenbeth, A., 2009. Rotational and continuous grazing of sheep in the Inner Mongolian steppe of China. J. Anim. Physiol. Anim. Nutr. 93, 245-252. doi:http://dx.doi.org/10.1111/j.1439-0396.2008.00810.x.

Yan, R., Xin, X., Yan, Y., Wang, X., Zhang, B., Yang, G., Liu, S., Deng, Y., Li, L., 2015. Impacts of differing grazing rates on canopy structure and species composition in hulunber meadow steppe. Rangel. Ecol. Manag. 68, 54-64. doi:http://dx.doi. org/10.1016/j.rama.2014.12.001.

ter Braak, C.J.F., Smilauer, P., 2002. CANOCO Reference Manual and CanoDraw for Windows User's Guide: Software for Canonical Community Ordination (version 4.5). .

van Klink, R., van der Plas, F., van Noordwijk Toos, C.G.E., WallisDeVries, M.F., Olff, H., 2015. Effects of large herbivores on grassland arthropod diversity. Biol. Rev. 90, 347-366. doi:http://dx.doi.org/10.1111/brv.12113.

van Noordwijk, C.G.E., Boer, P., Mabelis, A.A., Verberk, W.C.E.P., Siepel, H., 2012. Lifehistory strategies as a tool to identify conservation constraints: a case-study on ants in chalk grasslands. Ecol. Indic. 13, 303-313. doi:http://dx.doi.org/10.1016/j. ecolind.2011.06.028.

Zhu, H., Wang, D., Guo, Q., Liu, J., Wang, L., 2015. Interactive effects of large herbivores and plant diversity on insect abundance in a meadow steppe in China. Agric. Ecosyst. Environ. 212, 245-252. doi:http://dx.doi.org/10.1016/j. agee.2015.07.008. 